\title{
3. DIGITAL.CSIC
}

2 CIENCIA EN ABIERTO

El texto completo de este trabajo no se encuentra disponible por no haber sido facilitado aún por su autor, por restricciones de copyright, o por no existir una versión digital

The full text of this item is not available because it has not been provided by its author yet; because there are copyright restrictions; or because a digital version does not exist 